\title{
Seasonal movement patterns and habitat use of sub-adult Striped Bass Morone saxatilis in a highly managed and tidally influenced Pacific Coast Watershed
}

\author{
Cynthia M. Le Doux-Bloom (1D) Rebekah S. Lane • \\ Grant J. Christian • Catherine A. Masatani • \\ Jennifer E. Hemmert • A. Peter Klimley
}

Received: 9 July 2021 / Accepted: 23 November 2021 / Published online: 23 December 2021

(C) The Author(s) 2021

\begin{abstract}
Purposely introduced in 1879, Pacific coast Striped Bass Morone saxatilis once supported a commercial fishery and currently supports a recreational fishery in the San Francisco Estuary Watershed, CA, USA; however, the population has been in decline for decades. Since little is known about subadult behavior on the Pacific coast, we used acoustic telemetry to investigate seasonal movement patterns and habitat use across three regions (bay, delta, and river) and the effects of temperature and salinity on habitat use over a 2-year period. Sub-adult movement and habitat use differed by year and age. In spring, age-I and age-II sub-adults moved within the delta (60\%), river (20\%), and bay (20\%) regions,
\end{abstract}

Supplementary Information The online version contains supplementary material available at https://doi. org/10.1007/s10641-021-01197-2.

C. M. Le Doux-Bloom ( $\square)$

Department of Animal Science, University of California, Davis, Davis, CA, USA

e-mail: cledouxbloom@ucdavis.edu

C. M. Le Doux-Bloom - G. J. Christian · C. A. Masatani Department of Fisheries Biology, Humboldt State University, Arcata, CA, USA

\section{R. S. Lane}

Estuary \& Ocean Science Center, San Francisco State

University, Tiburon, CA, USA

R. S. Lane

The Marine Mammal Center, Sausalito, CA, USA and by summer, some individuals moved to the bay (36\%), while others remained in the delta (42\%) and river $(22 \%)$. Fall and winter showed equal movement between the bay and delta regions. During year 2, age-II and age-III fish inhabited the bay region across all seasons with the exception of spring when a few individuals migrated up river. Generally, subadults did not inhabit the river region in fall or winter. Sub-adults were not detected in water temperatures $<10{ }^{\circ} \mathrm{C}$ and occurred most often in $20-25{ }^{\circ} \mathrm{C}$. Younger sub-adults inhabited limnetic habitat where older fish inhabited mesohaline and polyhaline habitats. Our findings suggest that sub-adult seasonal movement patterns and habitat use hotspots have important fishery management implications and can be useful to address concerns over how this

\author{
J. E. Hemmert \\ California Department of Fish and Wildlife, Murrieta, CA, \\ USA
}

\author{
A. P. Klimley \\ Biotelemetry Laboratory, University of California, Davis, \\ Davis, CA, USA \\ A. P. Klimley \\ Biotelemetry Consultants, 2870 Eastman Lane, Petaluma, \\ CA, USA
}


non-native fish's predation impacts native and endangered fishes.

Keywords Striped Bass · Sub-adult · California · Telemetry $\cdot$ Movement $\cdot$ Habitat use

\section{Introduction}

Striped Bass Morone saxatilis (Walbaum) is a longlived, anadromous fish native to the US Atlantic seaboard with understudied populations on the Pacific coast. Striped Bass have a complicated life history which exhibits bimaturation, anadromy, and iteroparity. The commercial and recreational fisheries for Atlantic Striped Bass are of great economic importance and have grown extensively since the population recovered from its 1970s collapse, making this species one of the most targeted along the northeastern US coast (Hollema et al. 2017). Economic importance and fishery popularity have prioritized understanding the movement and habitat use across life stages (Secor and Piccoli 1996; Ng et al. 2007; Mather et al. 2010) by the agencies responsible for resource management and conservation efforts of Atlantic Striped Bass. Studies have revealed diverse and complicated life history strategies including movement and habitat use patterns in rivers (Dudley et al. 1977; Wingate and Secor 2007; Andrews et al. 2018), within and between estuaries (Haeseker et al. 1996; Able and Grothues 2007; Wingate et al. 2011), and the Atlantic Ocean (Kohlenstein 1981; Waldman et al. 1990; Kneebone et al. 2014).

Striped Bass was purposely introduced to the San Francisco Estuary Watershed (SFEW), CA, USA, in 1879 (Smith 1895), after the 1850s collapse of the salmon populations in the California Central Valley (California Fish Commission 1871; Lackey 2009). Twenty years after the release of 435 juvenile Striped Bass above San Pablo Bay near Carquinez Strait (Smith 1895), the population supported a commercial fishery with an annual catch of $454,000 \mathrm{~kg}$, but closed in 1935 to protect the sport fishery (Smith and Kato 1979). The SFEW currently supports an economically significant and popular recreational Striped Bass fishery; however, the population has remained in decline since the 1970s due to low egg production, reduced prey supply, water diversion-related entrainment, contaminant stressors, failed hatchery and stocking programs (Stevens et al. 1985; CDFG 1989), high legal and illegal harvest (Arthur et al. 1982), and the drought year of 1977 (Callahan et al. 1989). In 2001, the California Department of Fish and Wildlife (CDFW) ceased active management and stocking of Striped Bass over concerns that predation impacts native and endangered fishes (Lindley and Mohr 2002). The current CDFW fishing regulations allow catching of females prior to sexual maturity $(457 \mathrm{~mm}$ total length (TL)) which likely contributes to the overall population decline by reducing spawning biomass. Despite the population decline, the year-round Striped Bass recreational fishery's popularity continues to grow and accounts toward $24 \%$ of the $\$ 5.6$ billion economic output to California's recreational fishing industry (Allen et al. 2018; American Sportfishing Association 2021) as other target fish species decline and/or their fisheries experience seasonal or annual closures (e.g., Chinook salmon Oncorhynchus tshawytscha).

Knowledge of age and growth relationships are important when describing Striped Bass behavior, especially with sub-adult life stages (e.g., no egg or sperm visible upon palpating the vent). Edwards (1969) reported that growth rates in California are similar to most other US populations and compared studies on the San Francisco Bay (Robinson 1960) with Santee-Cooper Reservoir, South Carolina (Stevens 1957), and Chesapeake Bay, Maryland (Mansueti 1961), while growth was slower in Canada (Rulifson and Dadswell 1995). In the SFEW, female and male Striped Bass grow at the same rate until age-III (Robinson 1960). Atlantic Striped Bass males grow more slowly than females (Mansueti 1961). Males mature at age-II or older at 300-350 mm TL, while females mature after age-IV at lengths $>450 \mathrm{~mm}$ TL (Coutant 1986), but mostly after age-VI (Atlantic States Marine Fisheries Commission 2021). Turner and Kelley (1966) found that age-I Striped Bass in the San Joaquin Delta range from 120 to $230 \mathrm{~mm}$ fork length (FL) and 240 to $350 \mathrm{~mm}$ FL at age-II. In addition, Turner and Kelley (1966) and CDFW (2021) report that some males mature at age-II at $280 \mathrm{~mm}$ TL, but most mature at age-III, while females mature at ageIV-V at lengths $>533 \mathrm{~mm}$ TL.

Anadromous Striped Bass require estuarine and riverine habitats to complete their life cycle. Latitude plays a role between Striped Bass growth and the length of the growing season indicating the 
existence of a counter gradient relationship (Brown et al. 1998). Striped Bass occupy different habitat types (e.g., ocean, bay, estuary, and riverine) at different ages, and shifts in habitat are not simple responses to local conditions but reflect age-specific genetic adaptations (Coutant 1986). Temperature (Coutant 1985; Bjorgo et al. 2000) and salinity (Lal et al. 1977; Cook et al. 2010) influence Striped Bass movement and habitat use. Striped Bass are known to inhabit a wide thermal range $\left(6-27{ }^{\circ} \mathrm{C}\right)$ (Merriman 1941) with sub-adult and adults preferring different water temperature ranges (Coutant 1985). Striped Bass can be fully euryhaline (Tipsmark et al. 2004) with their salinity preference based on life stage (Cook et al. 2010) and sex (Kohlenstein 1981).

It has been long assumed that Pacific Striped Bass exhibit movement and habitat use similar to their Atlantic counterparts (Smith 1895). In the SFEW, studies have focused on adult Striped Bass (Calhoun 1952; Chadwick 1967; Sabal et al. 2019) with very few centered on sub-adults or analyzed separately from adults. The few notable exceptions reported variable conclusions including no definite movement patterns (Clark 1934; 1936), seasonal movements between the San Joaquin Delta and San Pablo Bay (Turner and Kelley 1966), and an ocean emigration lasting for at least 1 year (Scofield and Bryant 1926).

There is an incomplete knowledge of sub-adult Striped Bass behavior (Pautzke et al. 2010) and movement patterns (Able et al. 2012), especially along the Pacific coast (Boughton 2020). Knowledge of seasonal movement and habitat use of sub-adult Striped Bass are important to future population management considerations of this popular and economically important fishery, as well as accurately assessing their predatory impacts on native and endangered fishes in the SFEW.

Given the scant knowledge about sub-adult Striped Bass in the SFEW, we investigate seasonal movement and habitat use using acoustic tags and a fixed acoustic telemetry array over a 2-year period (2010-2012). This study investigates the following: (1) Does movement of sub-adult Striped Bass change between seasons and regions? (2) Does habitat use of sub-adult Striped Bass differ between seasons and regions? (3) Does water temperature, salinity, or the combination influence habitat use?

\section{Methods}

Study system and telemetry network

The SFEW is the largest estuary on the west coasts of North and South America and includes San Francisco Bay, Sacramento-San Joaquin Delta, and the Sacramento and San Joaquin River drainages (Cloern et al. 2011) (Fig. 1) and is widely recognized as the most invaded aquatic ecosystem in North America (Cohen and Carlton 1995). The SFEW is anthropogenically and geographically altered and very complex draining more than $194,000 \mathrm{~km}^{2}$ of Northern California (Conomos et al. 1985) through the central valley to the Pacific Ocean. The SFEW is one the most highly managed watersheds with regard to water export on the US Pacific coast after the Columbia River in Oregon. Although the SFEW's San Joaquin Delta serves as the hub of the water distribution system for California and provides water to $8 \%$ of the US population (Sommer 2020), it has a Mediterranean climate with highly variable annual precipitation patterns with dry conditions present in summer and fall with rainfall occurring in winter and spring.

Seasonal river flow, water temperature, and tidally influenced salinity levels facilitate reasonably clear habitat delineations into bay, delta, and river habitat regions. The bay region generally extends from the San Francisco Bay through Suisun Bay where seasonal water temperatures range from 10 to $20{ }^{\circ} \mathrm{C}$ in winter and summer, respectively, while the salinity gradient decreases from 30 to 5 practical salinity units (PSU) moving upstream in an eastwardly direction. The delta region blends the confluences of the Sacramento and San Joaquin rivers, and many small tributaries and canals. Although tidally influenced, the delta region has low salinity year-round with water temperatures ranging from 11 to $20{ }^{\circ} \mathrm{C}$. The river region starts where tidal effects cease on the Sacramento River about 20 river kilometers (rkm) downstream from the City of Sacramento and continues $155 \mathrm{rkm}$ upstream to the town of Colusa, about 15 rkm up the American River, and about 50 rkm up the Feather River. River region seasonal water temperatures range from 9 to $27{ }^{\circ} \mathrm{C}$ (data source: California Data Exchange Center (CDEC)).

In the SFEW, the California Fish Tracking Consortium maintains a large network of fixed Vemco 
Fig. 1 Map depicting receiver locations throughout the study area and color coded by habitat region (blue, bay; red, delta; green, river) in the San Francisco Estuary Watershed. Yellow crosses represent tag locations of study fish

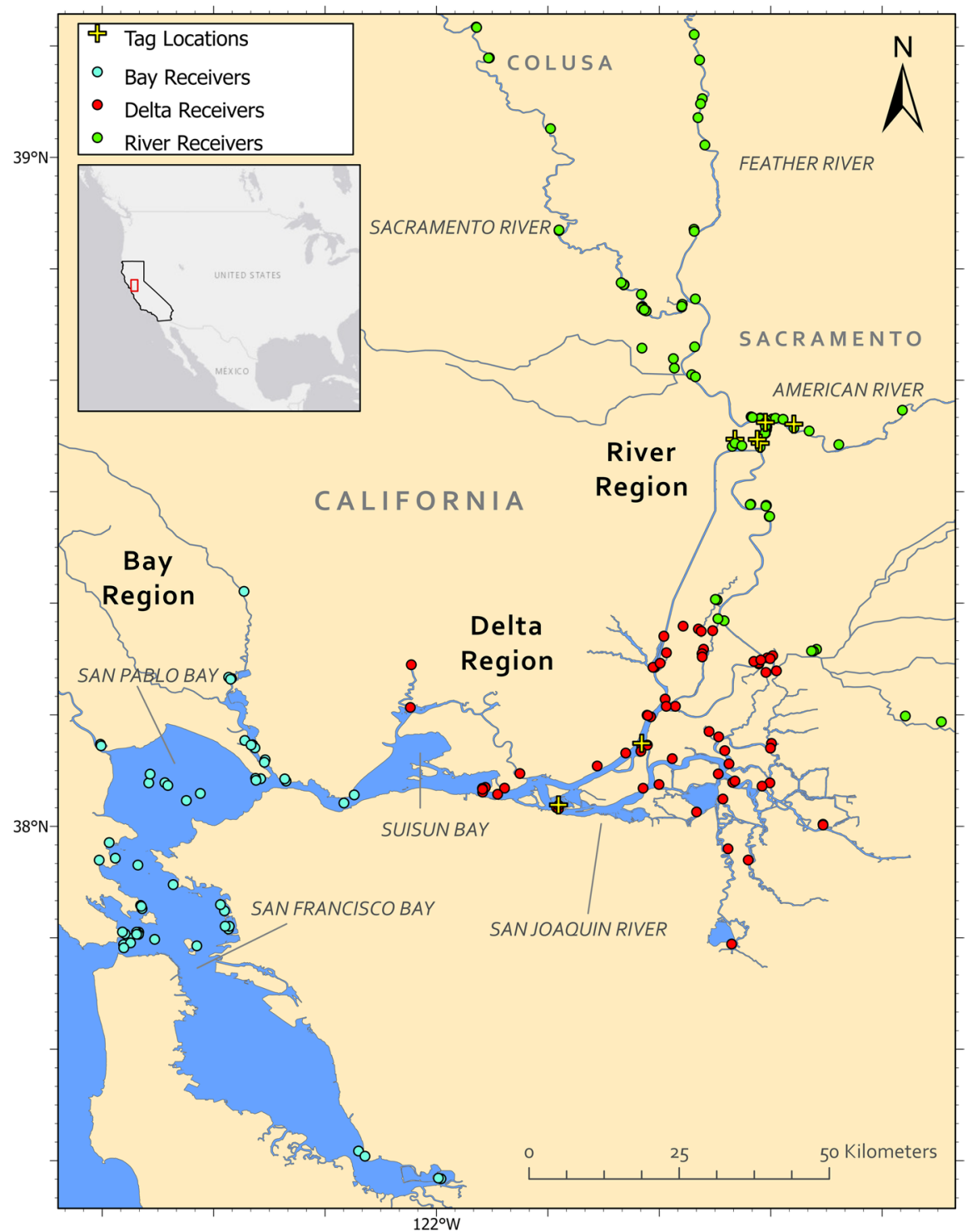

(AMIRIX Systems Inc., Halifax, Nova Scotia) $69 \mathrm{kHz}$ VR2/VR2W acoustic receivers that detect Vemco acoustic tags. Over 300 receivers were deployed from the confluence with the Pacific Ocean near San Francisco to the Sacramento River near Redding (0-586 rkm) and were grouped into habitat regions for analyses (Table 1; Fig. 1). Some receivers were periodically relocated by collaborating organizations throughout the study; thus, all units were not consistently available to collect continuous detections during the 2-year tracking period.
Fish capture and tagging

The tagging period of late spring and early summer was selected to facilitate the identification of subadult Striped Bass from post-spawned small males. Sub-adult Striped Bass of unknown sex, not exhibiting signs of sexual maturity, ranging from 225 to $350 \mathrm{~mm}$ TL were targeted for tagging. Fish were caught by hook and line, sedated with MS-222 in a concentration of $90 \mathrm{mg} / \mathrm{L}$ (Lemm 1993) buffered with sodium bicarbonate to maintain $\mathrm{pH} 7$ and implanted with acoustic tags (Vemco V-9; $29 \mathrm{~mm} ; 2.2 \mathrm{~g}$ in water; minimum battery life $=$ minimum 417 days; 
Table 1 Number of VEMCO Model VR2 receivers present by year and season in each habitat region $<350 \mathrm{rkm}$ in the San Francisco Estuary Watershed

\begin{tabular}{llllll}
\hline Year & Season & Bay & Delta & River & Total \\
\hline 2010 & Spring & 119 & 14 & 17 & 150 \\
& Summer & 125 & 14 & 22 & 161 \\
& Fall & 122 & 56 & 33 & 211 \\
$2011^{*}$ & Winter & 122 & 63 & 34 & 219 \\
& Spring & 150 & 54 & 125 & 329 \\
& Summer & 157 & 48 & 121 & 326 \\
& Fall & 153 & 55 & 106 & 314 \\
$2012^{*}$ & Winter & 154 & 52 & 131 & 337 \\
\hline
\end{tabular}

*Data fromSabal et al. (2019)

random ping $=90-120$ s). Tags were surgically implanted as described in Le Doux-Bloom (2012) to reduce drag and entanglement compared to external attachment (Bridger and Booth 2003). Fish were held less than $12 \mathrm{~min}$ from capture to release and released within a few meters of the capture site.

\section{Analyses of acoustic data}

Seasons were determined by identifying changes in water temperature (e.g., sharp increases or decreases) in the delta and river regions from data on the CDEC over the 2-year study period. Seasons were categorized as spring (Apr, May, Jun), summer (Jul, Aug, Sep), fall (Oct, Nov, Dec), and winter (Jan, Feb, Mar). To facilitate comparison of our acoustically tagged sub-adult Striped Bass with the only acoustically tagged adult Striped Bass study in the SFEW (Sabal et al. 2019), we adopted the habitat regions used in that study: bay region (rkm 0-70), delta region (rkm 70-170), and river region ( $\mathrm{rkm}>170)$.

Individual fish detections were examined for false detections using criteria defined by Vemco (Pincock 2012), and no false detections were found. In late spring, egg and larval Striped Bass are transported by river flow from spawning sites in the river region to the lower delta region near Suisun Bay (Turner and Kelley 1966). At some point, the age-I and age-II sub-adult Striped Bass that we tagged moved eastward farther into the delta and river regions. Since we do not know when this occurred, we used the capture date, time, and location as the first detection to identify the point of origin for each fish to identify changes in movement and habitat use patterns. Fish were assumed to have remained in the same habitat region in which last detected until detected in another habitat region. If fish were not detected during one season, but later detected again, they were assumed to have traveled outside receiver array coverage. Fish were divided into age classes based on age and growth information on sub-adult Striped Bass in the SFEW by Robinson (1960), Turner and Kelley (1966), and CDFW (2021); thus, age-I ranged from 225 to $279 \mathrm{~mm}$ TL and age-II ranged from 280 to $350 \mathrm{~mm}$ TL.

\section{Visual analyses}

The number of individual fish with $>30$ individual days of detections was used to analyze fish movement patterns to ensure sufficient temporal data (Sabal et al. 2019) and mapped using ArcGIS to visualize changes in distribution to observe the movement patterns by season and region. In ArcGIS, the Vemco tag identification numbers were simplified into unique counts of fish, and the receivers were clumped by region. Natural breaks determined breakpoints for the number of fish per abundance category depicted in the figure legends. This method simplified the visual analyses and facilitated the inference of seasonal movements between regions. Movement was defined as change in location within a region or transit into the adjacent region, while migration was defined as travel exceeding $100 \mathrm{rkm}$, generally from one habitat region through another and into the next habitat region (e.g., river to bay). Kernel density estimation $(\mathrm{KDE})$ is used to calculate the relative densities of features in an environment using a kernel function described by Silverman (1986). KDEs were completed using the Spatial Analyst toolbox in ArcGIS Pro version 2.7. KDEs were used to depict seasonal habitat use with the number of detections from all sub-adult Striped Bass to show unaltered presence by season and region (see Smultea et al. 2021). Univariate kernel density interpolations were created for fish detections for each month, aggregated into seasons and years, using planar distance and square map units. We classified relative density as the percentage of the total number of detections and categorized the densities as very high, high, medium, and low using the quantile method to indicate seasonal habitat use hotspots. 
Acoustic data combined with temperature and salinity

Some acoustic receivers and water quality monitoring stations were collocated providing fish detection data with water temperature $\left({ }^{\circ} \mathrm{C}\right)$ and salinity (PSU) data. Data sources included CDEC, California Environmental Data Exchange Network, Central and Northern California Ocean Observing System, National Estuarine Reserve Research Systems' Centralized Data Management Office, and United States Geological Survey. Water temperature and salinity data were categorized using the Coastal and Marine Ecological Classification System (CMECS) developed for the San Francisco Estuary (Federal Geographic Data Committee 2012). CMECS water temperature categories are defined as cold $\left(<10{ }^{\circ} \mathrm{C}\right)$, cool (10.1-15 $\left.{ }^{\circ} \mathrm{C}\right)$, moderate $\left(15.1-19.9{ }^{\circ} \mathrm{C}\right)$, and warm (20-25 $\left.{ }^{\circ} \mathrm{C}\right)$. CMECS categories of moderate and warm were slightly adapted to incorporate sub-adult Striped Bass temperature preference of $18-24{ }^{\circ} \mathrm{C}$ (Coutant 1986): moderate $\left(15.1-17.9^{\circ} \mathrm{C}\right.$ ) and warm $\left(18-25^{\circ} \mathrm{C}\right)$. CMECS salinity categories include euhaline $(>30.1 \%$ o), polyhaline $(18.1-30 \%$ ) , mesohaline (5.1-18.0\%o), oligohaline (0.51-5.0\%o), and limnetic $(<0.50 \%)$. The number of sub-adult Striped Bass seasonally inhabiting water temperature, salinity, and temperature-salinity combined was evaluated by age and year.

\section{Statistical analyses}

Pearson's chi-squared tests were used to evaluate if the movement patterns and habitat use of subadult Striped Bass were independent of season and region, season and age, and region and age. Movement pattern analyses included only individuals with $\geq 30$ individual days of detections, while habitat use included all detections. Pearson's chisquared tests were used to evaluate if habitat use was independent of age and water temperature, age and salinity, and the combinations of age and temperature-salinity. A Poisson Generalized Linear Model (GLM) was used to model movement patterns and habitat use of sub-adult Striped Bass as a function of year, age, season, and region. The level of significance $(\alpha)$ for statistical testing was 0.05 , and analyses were conducted using Program R (R Core Team 2020).

\section{Results}

Fish

In total, 74 sub-adult Striped Bass ranging in size from 225 to $340 \mathrm{~mm}$ TL (mean $\pm \mathrm{SD}=283 \pm 28 \mathrm{~mm}$ TL) were captured, tagged, and released in the delta $(n=53)$ and river $(n=21)$ regions in spring $(n=47)$ and summer $(n=27)$ from June 22 to July 6, 2010 (Table 2; Fig. 1). In the river region, capture of subadults proved more difficult due to capture of postspawned adults where this did not occur in the delta region. Following the post-tagging release, 72 of the 74 fish were detected by at least one receiver indicating high survival $(97 \%)$ consisting of $72 \%(n=52)$ from the delta and 28\% $(n=20)$ from the river regions. It is unknown if the two undetected tagged fish died, left the SFEW without being detected, or entered an area without receivers, or if the tag life ended prematurely. Our study fish included 36 age-I fish (delta $n=23$; river $n=13$ ) and 36 age-II (delta $n=29$; river $n=7$ ).
Table 2 Summary of subadult Striped Bass $(n=74)$ tagged in 2010 including date tagged, number of fish, mean total length \pm standard deviation, tag region, and tag location in the San Francisco Estuary Watershed

\begin{tabular}{llclll}
\hline Date tagged & $\begin{array}{l}\text { Number of } \\
\text { fish tagged }\end{array}$ & Mean total length $(\mathrm{mm})$ & Tag region & Tag latitude & Tag longitude \\
\hline 22-Jun & 12 & $287.25 \pm 36.25$ & Delta & $38.565383 \mathrm{~N}$ & $121.553497 \mathrm{~W}$ \\
23-Jun & 14 & $268.21 \pm 26.93$ & Delta & $38.111163 \mathrm{~N}$ & $121.692931 \mathrm{~W}$ \\
28-Jun & 10 & $271.2 \pm 24.85$ & River & $38.587980 \mathrm{~N}$ & $121.465384 \mathrm{~W}$ \\
29-Jun & 4 & $255 \pm 23.45$ & River & $38.565131 \mathrm{~N}$ & $121.520116 \mathrm{~W}$ \\
30-Jun & 7 & $270 \pm 27.08$ & River & $38.559373 \mathrm{~N}$ & $121.515738 \mathrm{~W}$ \\
6-Jul & 25 & $287.32 \pm 18.78$ & Delta & $38.019026 \mathrm{~N}$ & $121.817461 \mathrm{~W}$ \\
7-Jul & 2 & $310 \pm 35.36$ & Delta & $38.019026 \mathrm{~N}$ & $121.817461 \mathrm{~W}$ \\
\hline
\end{tabular}


Movement patterns

Seasonal movement patterns of sub-adult Striped Bass $(n=32$ with $>30$ days of individual detections; $n=232,457$ detections) varied between year, region, and age (Figs. 2 and 3; Supplementary Material-Table S1).

\section{Age-I and age-II}

In spring, equal numbers of age-I and age-II fish were counted $(n=10)$ with $60 \%$ (age-I $n=4$; ageII $n=2$ ) observed in delta, 20\% in the bay (age-I $n=1$; age-II $n=1$ ), and $20 \%$ in the river (age-I $n=0$; age-II $n=2$ ) regions (Fig. 2; Supplementary Material-Table S1). In summer, 74 fish were counted with $42 \%$ (age-I $n=13$; age-II $n=18$ ) in the delta, 36\% (age-I $n=11$; age-II $n=16$ ) in the bay, and 22\% (age-I $n=7$; age-II $n=9$ ) in the river regions. Over the summer, sub-adults moved from the river region into the delta and bay regions. In fall, 43 fish were observed with 53\% (age-I $n=10$; age-II $n=13$ ) in the bay and 44\% (age-I $n=6$; ageII $n=13$ ) in the delta regions and 2.3\% (age-I $n=1$; age-II $n=0$ ) in the river region. In winter, 30 fish were counted with $53 \%$ (age-I $n=6$; age-II $n=10$ ) in the bay and $47 \%$ (age-I $n=4$; age-II $n=10$ ) in the delta regions, and zero fish in the river region. Age-II fish were counted more often than age-I individuals $(59 \% ; 41 \%)$.

Overall, age-I and age-II fish moved westward from the river region into the delta and bay regions from spring to winter. In spring, fish moved within the delta region. In summer, fish were moving between and within regions and transited equally between the bay and delta regions in the fall and winter. From fall to winter, fish continued to move into the bay region and closer to the confluence with the Pacific Ocean. One age-II fish moved past the Golden Gate Bridge receivers in San Francisco Bay and into the Pacific Ocean in late winter and returned in late spring. After summer, fish were not generally observed in the river region. The highest numbers of fish were counted in the areas just above Suisun Bay in the delta region and just below Suisun Bay and San Pablo Bay in the bay region across all seasons.
Age-II and age-III

In spring, 31 sub-adult-Striped Bass were counted with 55\% (age-II $n=6$; age-III $n=11$ ) in the bay, 35\% (age-II $n=5$; age-III $n=6$ ) in the delta, and 10\% (ageII $n=1$; age-III $n=2$ ) in the river regions (Fig. 3; Supplementary Material-Table S1). In summer, 20 fish were counted with 55\% (age-II $n=4$; age-III $n=7$ ) in the bay, $30 \%$ (age-II $n=2$; age-III $n=4$ ) in the delta, and 15\% (age-II $n=1$; age-III $n=2$ ) in the river regions. In fall, six fish were observed with $67 \%$ (age-II $n=2$; age-III $n=2$ ) in the bay and 33\% (age-II $n=1$; age-III $n=1$ ) in the delta regions, and zero in the river region. In winter, 10 fish were counted with $50 \%$ (age-II $n=2$; age-III $n=3$ ) in the bay and $40 \%$ (age-II $n=1$; age-III $n=3$ ) in the delta regions with $2.3 \%$ (age-II $n=0$; age III $n=1$ ) in the river region. This fish moved into the river region on the last day of winter. Age-III fish were observed more often than age-II individuals $(61 \% ; 39 \%)$.

Overall, age-II and age-III fish moved nearly equally between the bay and delta regions in spring, summer and winter, and movement increased into the bay region in fall. After spring and summer, fish were generally not observed in the river region. The highest numbers of fish were counted below Suisun Bay, San Pablo Bay, and San Francisco Bay in the bay region across all seasons and above Suisun Bay near the confluence with the Sacramento and San Joaquin rivers in the delta region in winter.

The seasonal movement patterns of all age sub-adult Striped Bass differed between regions $\left(\chi^{2}=36.4, p=0.0009\right)$ and years (year $1: \chi^{2}=69,049$, $p<0.001$; year 2: $\chi^{2}=2326, p=0.001$ ) (Table 3). Both the seasonal and regional movement patterns differed by age (season: age-I and age-II: $\chi^{2}=54,354$, $p<0.001$; age-II and age-III: $\chi^{2}=831, p<0.001$ ) (region: age-I and age-II: $\chi^{2}=15,676, p<0.001$; ageII and age-III: $\left.\chi^{2}=235, p<0.001\right)$. There were differences in the movement patterns of sub-adult Striped Bass between years (GLM: $t=-1.77, p=0.0001$ ) and ages (GLM: $t=2.15, p=0.03$ ). Spring 2010 (GLM: $t=-2.31, p=0.02$ ) and spring 2011 (GLM: $t=2.81, p=0.007)$ were different from one another, while summer 2010 (GLM: $t=2.56, p=0.01$ ) was different from all other seasons and years. There was a difference in movement patterns between the bay and river regions (GLM: $t=-5.63, p=0.0001$ ), but not the bay and delta regions. 


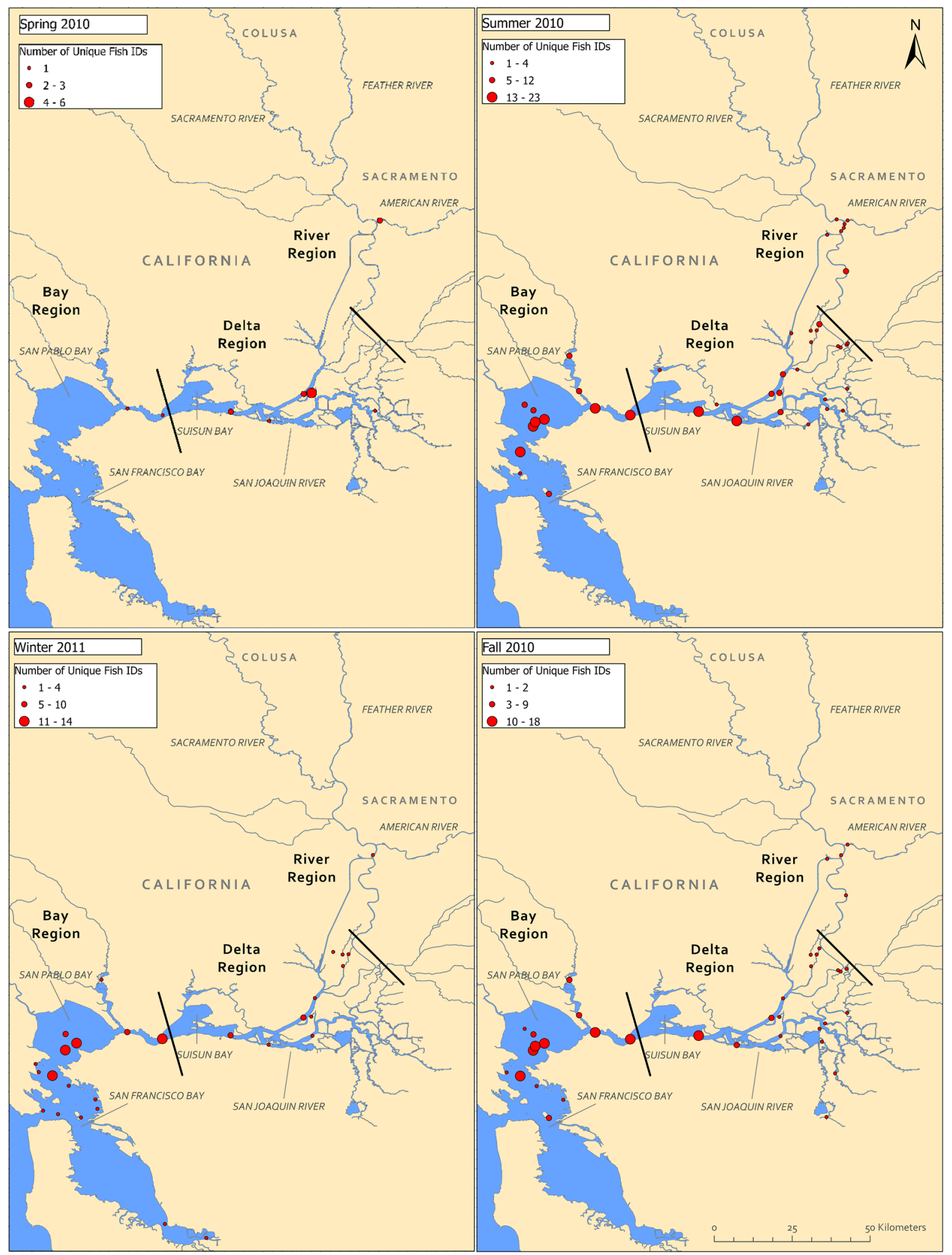


4Fig. 2 Seasonal movement of age-I and age-II sub-adult Striped Bass based on unique fish IDs at receiver from spring 2010 to winter 2011 in the San Francisco Estuary Watershed

\section{Habitat use}

Seasonal habitat use by sub-adult Striped Bass ( $n=250,461$ detections; $n=72$ fish) varied between year, region, and age (Figs. 4 and 5; Supplementary Material-Table S2).

\section{Age-I and age-II}

A total of 217,608 detections were recorded by age-I and age-II sub-adult Striped Bass $(n=44)$ from spring 2010 to winter 2011. In spring, sub-adult Striped Bass recorded 4,389 detections with 52\% (age-I $n=1,431$; age-II $n=871$ ) observed in delta, $44 \%$ in the bay (age-I $n=1,944$; age-II $n=2$ ), and $3 \%$ in the river (age-I $n=84$; age-II $n=57$ ) regions (Supplementary Material-Table S2). In summer, the number of detections increased to 90,274 with 54\% (age-I $n=11,365$; age-II $n=37,029$ ) observed in delta, $32 \%$ in the bay (age-I $n=5,240$; age-II $n=23,369$ ), and $14 \%$ in the river (age-I $n=8,868$; age-II $n=4,403$ ) regions. In fall, fish were detected 96,360 times with 93\% (age-I $n=69,617$; age-II $n=19,689$ ) observed in the bay, $7 \%$ in delta (age-I $n=4,637$; age-II $n=2,404$ ), and $<1 \%$ in the river (age-I $n=13$; ageII $n=0)$ regions. In winter, 26,617 detections were recorded with $73 \%$ (age-I $n=9,630$; age-II $n=9,904$ ) in the bay and 27\% (age-I $n=3,958$; age-II $n=3,125$ ) in the delta regions, with zero detections in the river region.

\section{Age-II and age-III}

A total of 32,853 detections were recorded by ageII and age-III sub-adult Striped Bass $(n=28)$ from spring 2011 to winter 2012. In spring, sub-adult Striped Bass were detected 19,904 with 89\% (age-II $n=10,638$; age-III $n=6,352$ ) of detections observed in the bay, $4 \%$ in the delta (age-II $n=115$; age-III $n=686$ ), and $7 \%$ in the river (age-II $n=87$; ageIII $n=1,210$ ) regions (Supplementary MaterialTable S2). In summer, sub-adult Striped Bass were detected 9,027 with $72 \%$ (age-II $n=1,852$; age-III $n=4,665$ ) observed in the bay, $17 \%$ in the delta (ageII $n=1,311$; age-III $n=238$ ), and $11 \%$ in the river
(age-II $n=827$; age-III $n=134$ ) regions. In fall, 484 detections were recorded with $65 \%$ (age-II $n=262$; age-III $n=54$ ) observed in the bay and $35 \%$ in the delta (age-II $n=159$; age-III $n=9$ ) regions, with zero detections in the river region. In winter, detections increased to 4,254 with $87 \%$ (age-II $n=2,668$; age-III $n=1,017$ ) observed in the bay, $13 \%$ in the delta (ageII $n=213$; age-III $n=326$ ), and $<1 \%$ (age-II $n=30$; age-III $n=0$ ) in the river regions.

Overall, sub-adult Striped Bass inhabited the bay region across all age classes: age-I (76\%) and age-II (53\%) in year 1 and age-II (85\%) and age III (83\%) in year 2 . The delta region was inhabited more than the river region by all age classes: age-I (18\%) and age-II $(43 \%)$ in year 1 and age-II (10\%) and age III (8\%) in year 2 . The river region was inhabited by age-I (6\%) and age-II (4\%) in year 1 and age-II (5\%) and age III (9\%) in year 2. Both the bay and delta regions were inhabited by sub-adult Striped Bass across all seasons, while the river region was inhabited in spring and summer only and generally not used in fall and winter.

KDE results depict the density of detections of sub-adult Striped Bass by season, region, and year and provide visual analyses of habitat use and high use hotspots (Figs. 4 and 5). In spring year 1, very high to medium densities of detections occurred in the upper portion of the bay region below Suisun Bay and in the delta region above Suisun Bay (Fig. 4). In summer, the upper San Francisco Bay and lower San Pablo Bay in the bay region and confluences of the Sacramento and San Joaquin rivers in the delta region had very high-medium densities, with very high-density hotspots near the confluences of the Sacramento and American rivers in the river region. In fall, hotspots of very high densities were located in the bay region in the San Pablo Bay and delta region above Suisun Bay. In winter, very high-low densities occurred in the bay region extending from lower San Pablo Bay toward the confluence with the Pacific Ocean with a few very high-medium hotspots in the delta region.

In spring year 2, very high-low densities remained in most of the bay region in San Pablo and San Francisco bays, while medium density occurred near the confluence with the Pacific Ocean (Fig. 5). Additionally, medium-low densities occurred above Suisun Bay in the delta region. High-low densities occurred near the confluences with the Sacramento and 


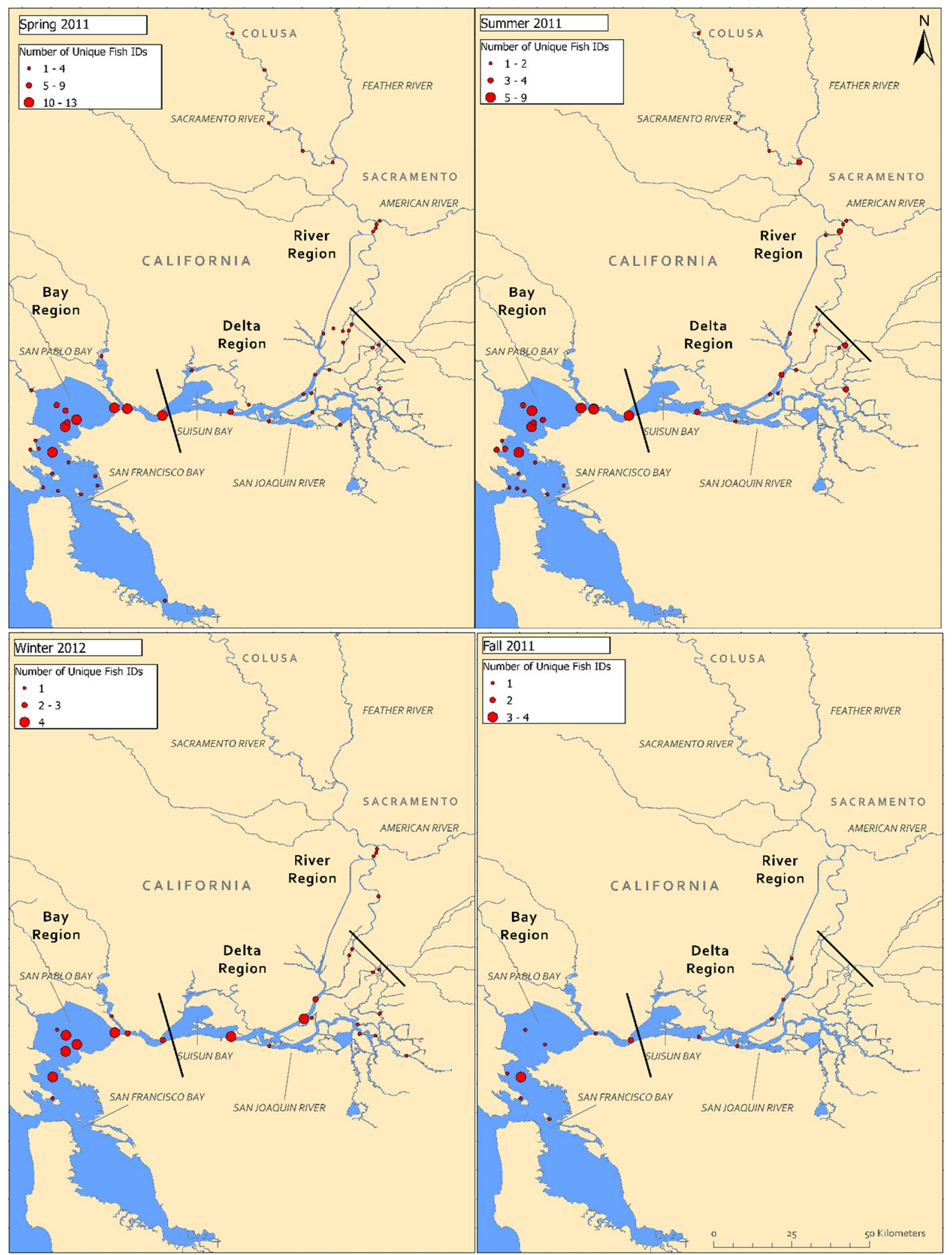


4Fig. 3 Seasonal movement of age-II and age-III sub-adult Striped Bass based on unique fish IDs at receiver from spring 2011 to winter 2012 in the San Francisco Estuary Watershed

American rivers and very high-medium densities near the confluences of the Sacramento and Feather rivers in the river region. In summer, high density was recorded near the confluence with the Pacific Ocean with very high densities recorded in the upper San Francisco and San Pablo bays in the bay region. The delta region depicted medium density in and above Suisun Bay, and the river region showed hotspots of very high densities below the confluences of the Sacramento and American rivers and above the confluences of the Sacramento and Feather rivers. In fall, the bay region had large areas of very high-medium densities in the upper San Francisco and San Pablo bays, where the delta region ranged from very high to medium density with the hotspots recorded below Suisun Bay and lower Sacramento River. In winter, very high-medium densities were recorded in the upper San Francisco Bay, the center of San Pablo Bay, and below Suisun Bay in the bay region, while high-medium densities occurred in the delta region above Suisun Bay.

Overall, the upper San Francisco and San Pablo bays were hotspots in the bay region for all age fish except for age-I and age-II fish in spring 2010. Seasonal hotspots occurred near the confluence with the Pacific Ocean in summer 2011, while medium density occurred in winter and fall 2011. The delta region had hotspots above Suisun Bay across all seasons in 2010-2011 and in summer 2011. The river region showed hotspots in summer 2010, spring 2011, and summer 2011 near the confluences of the Sacramento and American rivers and Sacramento and Feather rivers.

The seasonal habitat use of all age sub-adult Striped Bass differed between regions $\left(\chi^{2}=83,079\right.$, $p<0.0001$ ) and years (year 1: $\chi^{2}=80,349, p<0.001$; year 2: $\chi^{2}=2201, p<0.001$ ) (Table 3). Seasonal and regional habitat use differed between age (season: age-I and age-II: $\chi^{2}=45,969, p<0.001$; age-II and age-III: $\chi^{2}=965.4, p<0.001$ ), and (region: age-I and age-II: $\chi^{2}=15,945, p<0.001$; age-II and age-III: $\left.\chi^{2}=204.3, \mathrm{p}<0.001\right)$. There were differences in the habitat use between years (GLM: $t=-2.7, p=0.01$ ) and spring 2010 (GLM: $t=-3.09, p=0.006$ ) and winter 2011 (GLM: $t=-1.29, p=0.009$ ). There was a difference in habitat use between the bay and delta regions (GLM: $t=-2.91, p=0.006$ ) and river region (GLM: $t=-2.36, p=0.0002$ ).

Temperature and salinity

Some acoustic receivers and water quality monitoring stations ( $n=102$; bay $n=34$; delta $n=45$; river $n=23$ ) were collocated and provided a total of 537 detections, 327 in year 1 (bay $n=90$; delta $n=205$; river $n=32$ ) and 210 in year 2 (bay $n=159$; delta $n=24$; river $n=33$ ) with water temperature $\left({ }^{\circ} \mathrm{C}\right)$ and salinity (PSU) data. In year 1, age-I sub-adult Striped Bass occurred more in limnetic habitat than age-II individuals, while age-II fish occurred more in higher salinity habitats such as mesohaline and polyhaline (Table 3; Supplementary Material-Table S3). In year 2, age-II fish occurred more in warm-limnetic habitat than age-III. Age-III fish occurred less than expected in warm-limnetic habitat. Water temperature influenced sub-adult Striped Bass habitat use $\left(\chi^{2}=44.9\right.$, $p=0.0001$ ), but this effect did not differ between age-I and age-II $\left(\chi^{2}=0.09, p=0.96\right)$ or age-II and age-III $\left(\chi^{2}=3.78, p=0.15\right)$. Salinity influenced subadult Striped Bass habitat use $\left(\chi^{2}=75.7, p=0.0001\right)$ and affected age-I and age-II $\left(\chi^{2}=44.7, p=0.001\right)$, but not age-II and age-III $\left(\chi^{2}=5.91, p=0.21\right)$. Temperature-salinity combined affected sub-adult Striped Bass habitat use $\left(\chi^{2}=185.5, p=0.0001\right)$ and between age-I and age-II $\left(\chi^{2}=53.8, p=0.001\right)$ and age II and age-III $\left(\chi^{2}=40.7, p=0.001\right)$.

\section{Discussion}

Sub-adult Striped Bass seasonal movement and habitat use differed between years and ages making patterns evident and showed similarities with earlier sub-adult studies in the SFEW. In spring, Turner and Kelley (1966) reported the following: (1) The distribution of sub-adult male Striped Bass resembled that of adult males with fish in the Sacramento River migrating upstream. (2) Sub-adults in the San Joaquin River remained in the delta region. (3) Subadult males from the delta migrated to the Sacramento River (e.g., river region) and later migrated to San Pablo Bay (e.g., bay region). (4) Some subadult males remained in the delta and few immature females migrated from the bay into the delta. Age-I 
Table 3 Statistical results using chi-square and generalized linear model tests based on movement patterns and habitat use of subadult Striped Bass by year, age, season, and region in the San Francisco Estuary Watershed

\begin{tabular}{|c|c|c|c|c|c|c|c|c|c|c|c|}
\hline \multicolumn{12}{|l|}{ Distribution } \\
\hline \multicolumn{7}{|l|}{$X^{2}$ test } & \multicolumn{5}{|l|}{ GLM tests } \\
\hline \multirow[t]{2}{*}{ Age } & \multicolumn{2}{|c|}{$\begin{array}{l}\text { Year 1-2 } \\
\text { Ages I-II, II-III }\end{array}$} & \multicolumn{2}{|c|}{$\begin{array}{l}\text { Year } 1 \\
\text { Age I-II }\end{array}$} & \multicolumn{2}{|c|}{$\begin{array}{l}\text { Year } 2 \\
\text { Age II-III }\end{array}$} & \multirow[b]{2}{*}{ Intercept } & \multirow{2}{*}{$\begin{array}{l}\text { Estimate } \\
3.55\end{array}$} & \multirow{2}{*}{$\begin{array}{l}\text { SE } \\
0.5\end{array}$} & \multirow{2}{*}{$\begin{array}{l}t \text {-value } \\
7.1\end{array}$} & \multirow{2}{*}{$\begin{array}{l}p \text {-value } \\
0.0001 *\end{array}$} \\
\hline & $X^{2}$ & $p$ & $X^{2}$ & $p$ & $X^{2}$ & $p$ & & & & & \\
\hline Season-region & 36.4 & $0.0009^{*}$ & 69,049 & $0.001 *$ & 2326 & $0.001 *$ & Year & -1.77 & 0.41 & -4.23 & $0.0001 *$ \\
\hline Season-age & & & 54,354 & $0.001^{*}$ & 830.6 & $0.001 *$ & Age & 0.31 & 0.14 & 2.15 & $0.03 *$ \\
\hline \multirow[t]{9}{*}{ Region-age } & & & 15,676 & $0.001 *$ & 235.3 & $0.001 *$ & Spr 2010 & -0.67 & 0.29 & -2.31 & $0.02 *$ \\
\hline & & & & & & & Spr 2011 & 1.13 & 0.4 & 2.81 & $0.007 *$ \\
\hline & & & & & & & Sum 2010 & 0.54 & 0.21 & 2.56 & $0.01 *$ \\
\hline & & & & & & & Sum 2011 & 0.69 & 0.43 & 1.62 & 0.11 \\
\hline & & & & & & & Fal 2011 & -0.51 & 0.57 & -0.89 & 0.38 \\
\hline & & & & & & & Win 2011 & -0.21 & 0.25 & -0.82 & 0.42 \\
\hline & & & & & & & Win 2012 & N/A & N/A & N/A & N/A \\
\hline & & & & & & & Delta & -0.02 & 0.15 & -0.12 & 0.9 \\
\hline & & & & & & & River & -1.31 & 0.23 & -5.63 & $0.0001^{*}$ \\
\hline \multicolumn{12}{|l|}{ Habitat use } \\
\hline Season-region & 83,079 & $0.0001^{*}$ & 80,349 & $0.001 *$ & 2201 & $0.001 *$ & & Estimate & SE & $t$-value & $p$-value \\
\hline Season-age & & & 45,969 & $0.001 *$ & 965.4 & $0.001 *$ & Intercept & 13.6 & 1.13 & 12 & $0.0001 *$ \\
\hline Region-age & & & 15,945 & $0.001 *$ & 204.3 & $0.001 *$ & Year & -2.97 & 1.1 & -2.7 & $0.01 *$ \\
\hline Temp-age & 44.9 & $0.0001 *$ & 0.09 & 0.96 & 3.78 & 0.15 & Age & -0.16 & 0.28 & -0.56 & 0.57 \\
\hline Sal-age & 75.7 & $0.0001 *$ & 44.7 & $0.001 *$ & 5.91 & 0.21 & Spr 2010 & -3.09 & 1.05 & -2.94 & $0.006^{*}$ \\
\hline \multirow[t]{8}{*}{ Temp-sal-age } & 185 & $0.0001 *$ & 53.8 & $0.001 *$ & 40.7 & $0.001 *$ & Spr 2011 & 1.50 & 1.15 & 1.31 & 0.20 \\
\hline & & & & & & & Sum 2010 & -0.06 & 0.31 & -0.21 & 0.84 \\
\hline & & & & & & & Sum 2011 & 0.76 & 1.27 & 0.60 & 0.55 \\
\hline & & & & & & & Fal 2011 & -2.17 & 3.27 & -0.67 & 0.51 \\
\hline & & & & & & & Win 2011 & -1.29 & 0.47 & -2.73 & $0.009 *$ \\
\hline & & & & & & & Win 2012 & N/A & N/A & N/A & N/A \\
\hline & & & & & & & Delta & -0.90 & 0.31 & -2.91 & $0.006 *$ \\
\hline & & & & & & & River & -2.36 & 0.57 & -4.17 & $0.0002 *$ \\
\hline
\end{tabular}

$* p \leq 0.05$

and age-II sub-adults in this study demonstrated very similar movement patterns and habitat use in spring. In spring 2010, sub-adult Striped Bass were present in the river region in areas not associated with spawning in the Sacramento River below the confluence with the American River. It is unknown when these sub-adults moved upstream from the delta to the river region when tagged for our study and may have moved upstream as water temperatures increased above $15{ }^{\circ} \mathrm{C}$, followed prey sources such as emigrating juvenile salmonids, followed adult male pheromone cues toward spawning areas or a combination. We captured many post-spawned males along with sub-adults while fishing in the river region; thus, maybe immature males migrated from the bay and delta regions with adult males in early spring. In summer, Turner and Kelley (1966) noted that sub-adult Striped Bass were abundant in the delta. Raney (1952) found that by age-II, subadults began to school and fed heavily on other species of schooling fish. Our sub-adult Striped Bass movement patterns and habitat use concur with Turner and Kelley (1966) regarding their delta observations. By late summer of both years, some sub-adults had moved into the bay and exhibited wide seasonal movement patterns and habitat use 
spanning variable temperatures and salinities. In fall, Turner and Kelley (1966) reported the following: (1) Sub-adult Striped Bass moved from the Delta to the bay region near San Pablo Bay. (2) Sub-adult Striped Bass moved downstream from the delta in large numbers, while a smaller part of the population remained in the Delta throughout the year. (3) Sub-adult Striped Bass distribution overlapped with threadfin shad (Dorosoma petenense) presence. (4) Sub-adult Striped Bass moved from the delta seeking warmer water, food supply, or both. It appears that fall movement patterns and habitat use by sub-adults may be driven by foraging behavior. Our sub-adult Striped Bass movement patterns and habitat use concur with Turner and Kelley (1966). In both years, age-II fish spent fall inhabiting the delta and bay regions. In winter, Turner and Kelley (1966) found the following: (1) Sub-adult population was relatively low in the delta but appeared to increase in late spring. (2) The concentration of age-I and age-II remained low in the Delta but remained high in San Pablo Bay. (3) Age-I fish overwintered in the Delta. (4) Water temperatures in mudflats near San Pablo Bay in the bay region and the Pacific Ocean were warmer than the Delta, and fish shifted toward the bay. Our sub-adult Striped Bass also spent winter inhabiting the delta and bay regions over all ages and both years. In spring 2011, the movement patterns and habitat use changed significantly. Some sub-adults shifted from the bay and delta regions into the delta and river regions. Based upon movement patterns and habitat use patterns, some of the age-III fish were males that became sexually mature and migrated over 100 rkm up the Sacramento River to spawning areas near Colusa. Additionally, in summer 2011, movement patterns of fish into the delta region increased. Turner and Kelley (1966) showed that sexually maturing males moved into the delta during the spring and immature females moved into the delta in late spring and summer. Females may be moving into the delta region for warmer temperatures and to feed on the prey present due to the males migrating to the spawning areas in the river region. Chadwick (1967) found that few sub-adult females moved from the bay into the delta prior to sexual maturity. This could explain the high movement patterns and habitat use hotspots in the bay region across years and seasons. Also, it may indicate that more females were tagged than males in the delta in early summer. Overall, our study results concurred closely with Turner and Kelley (1966). This is interesting when one considers the drastic anthropogenic changes which have occurred in the SFEW over the 50 years since their study.

Migration timing of sub-adult Striped Bass to the Pacific Ocean remains unclear. Several sub-adults were detected by Golden Gate Bridge receivers in San Francisco Bay between winter, summer, and fall 2011. Scofield and Bryant (1926) speculated that large "sea growth" occurred in age-II sub-adult Striped Bass based on high catches in the fall and winter by shrimp nets fishing between San Pablo and San Francisco bays. Skinner (1962) speculated that ocean migration began at age-II and age-III although many fish wait until age-IV or later. Turner and Kelley (1966) reported that few sub-adults were caught from late summer to mid-winter which leads us to speculate that sub-adults may migrate to the ocean to avoid water temperatures $<10{ }^{\circ} \mathrm{C}$ and potentially encounter more abundant prey.

Sabal et al. (2019) analyzed acoustically tagged adult Striped Bass data from individuals caught in the SFEW's river region in late spring and early summer over four years. Adult Striped Bass inhabited the bay and delta regions in summer and fall, delta region in the winter, and river region during spring associated with spawning. Other historic studies on adults found a spawning migration in the spring and a second migration in the fall. Although Sabal et al. (2019) found adult movement variable, individuals increased river residence in spring, inhabited the bay region in summer, and the delta, bay, and river regions in fall and winter. Sub-adults demonstrated similar patterns in spring and summer, but generally were not present in the river in fall or winter. Adult studies concluded that seasonal movement may follow seasonal prey such as juvenile salmonids which are abundant in rivers in the spring, while forage fish (e.g., Northern anchovy Engraulis mordax) are abundant in the bay region over summer. We agree that seasonal movement patterns by sub-adults likely follow seasonal prey. Synthesis of data sets describing acoustically tagged juvenile Chinook salmon movements (Buchanan et al. 2018; Pope et al. 2021) with detections from acoustically tagged Striped Bass may illuminate 


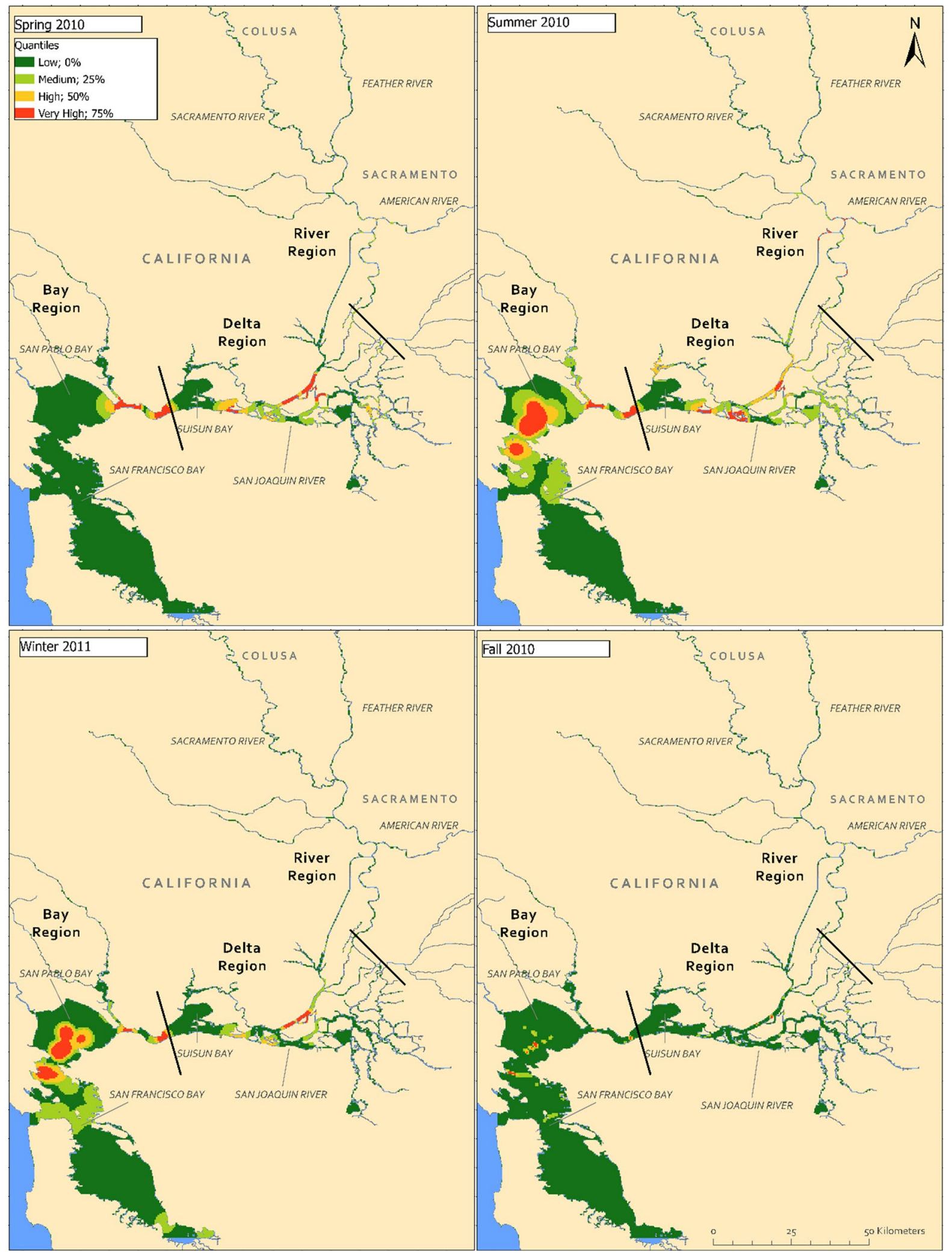


4Fig. 4 Seasonal habitat use using kernel density interpolations of age-I and age-II sub-adult Striped Bass based upon the detections $(n=217,609)$ from spring 2010 to winter 2011 in the San Francisco Estuary Watershed

finer scale movement patterns and habitat use relationships impacting juvenile salmonid survival in the SFEW.

Sub-adult Striped Bass have warmer thermal preferences than adults which may act as a thermal separator of sub-adult and adult habitats, supporting a component of the nursery role hypothesis (Beck et al. 2001). Sub-adult Striped Bass have displayed maximum growth and minimum maintenance ration near $24{ }^{\circ} \mathrm{C}$ (Cox and Coutant 1981). Our sub-adults inhabited the warmest water temperature habitat available. It may be that the movement patterns of immature females and mature males obscured differences between age-I and age-II fish and age-II and age-III fish. During winter, the delta and bay regions were approximately the same water temperature as the nearshore Pacific Ocean which makes us ponder the concept of a winter migration of sub-adult Striped Bass into the ocean and a return of immature females in summer and fall. Chadwick (1967) recaptured ocean tag returns in summer, fall, and winter with peaks in July and August indicating that age-I and age-II fish seasonally migrate into the Pacific Ocean. This would account for the low number of detections in fall and winter and detections near the confluence with the Pacific Ocean in summer and fall. Age-I and age-II fish inhabited different salinity levels than age-II and age-III individuals. Younger fish spent more time in limnetic water, while older fish spent more time in higher salinity habitats. We suspect that the divide in salinity preferences between females and males in age-I and age-II fish may derive from the concept that some males reach maturity at age-II while others at age-III and that immature fish may be schooling together. Interestingly, Patrick et al. (2006) studied otoliths from Roanoke River, North Carolina, age-I Striped Bass and found three movement patterns. Residents remained in oligohaline waters like those found in the delta region, stagers moved from oligohaline to mesohaline to euhaline waters, and sprinters moved from oligohaline to euhaline waters (e.g., delta to bay region). Our age-I fish demonstrated similar movement and habitat use patterns. The concept that immature and mature males may be resident while immature females could be stagers and sprinters warrant further investigation in the SFEW and could impact predation pressure on native and endangered fishes and seasonal fishing pressure in hotspot areas in the delta and bay regions depicted by the KDE analyses. Increased piscivory by juvenile Striped Bass was linked with decreasing salinity (Cooper et al. 1998; Nemerson and Able 2003) which aligns with seasonal habitat use in the delta region and may help explain why sub-adult fish moved up to the river region in spring 2010 when we tagged them. Our findings show that the majority of sub-adults Striped Bass did not inhabit the river region unless associated with the timing of the spring spawning migration.

\section{Fishery management implications}

Following the decline of salmonids in the California Central Valley (California Fish Commission 1871; Lackey 2009), the California Fish Commission began the enhancement of fisheries by introducing many species to California including Striped Bass (California Fish Commission 1879; Towle 2000) and shortly afterward the species demonstrated Pacific Coast migrations (Morgan and Gerlach 1950; Forrester et al. 1972). Although Pacific Striped Bass remains one of the few highly successful introductions of non-native fishes (Raney 1952) supporting a century-long popular fishery, serious concern exists about the species' predatory impacts on native and endangered fishes. Although anthropogenic landscape scale changes in the SFEW over the past century have decreased or eliminated sufficient habitat for both native salmonids and introduced species, like Striped Bass, neither species has experienced population recovery. Historically, when the Pacific Striped Bass population required greater protection, the commercial fishery was closed to protect the recreational fishery, and the catch length was incrementally increased from daily bag limits of five fish $>305 \mathrm{~mm}$ TL ( $>12$ inches TL), to three fish $>406 \mathrm{~mm}$ TL ( $>16$ inches TL), to the current two fish $>457 \mathrm{~mm}$ TL ( $>18$ inches TL) which continues to permit the capture of immature females. Chadwick (1967) found that the bay sport fishery was composed of sub-adults indicating that they do not migrate. Movement patterns and habitat use analyses showed hotspots in the bay region across most seasons, ages, and years. 


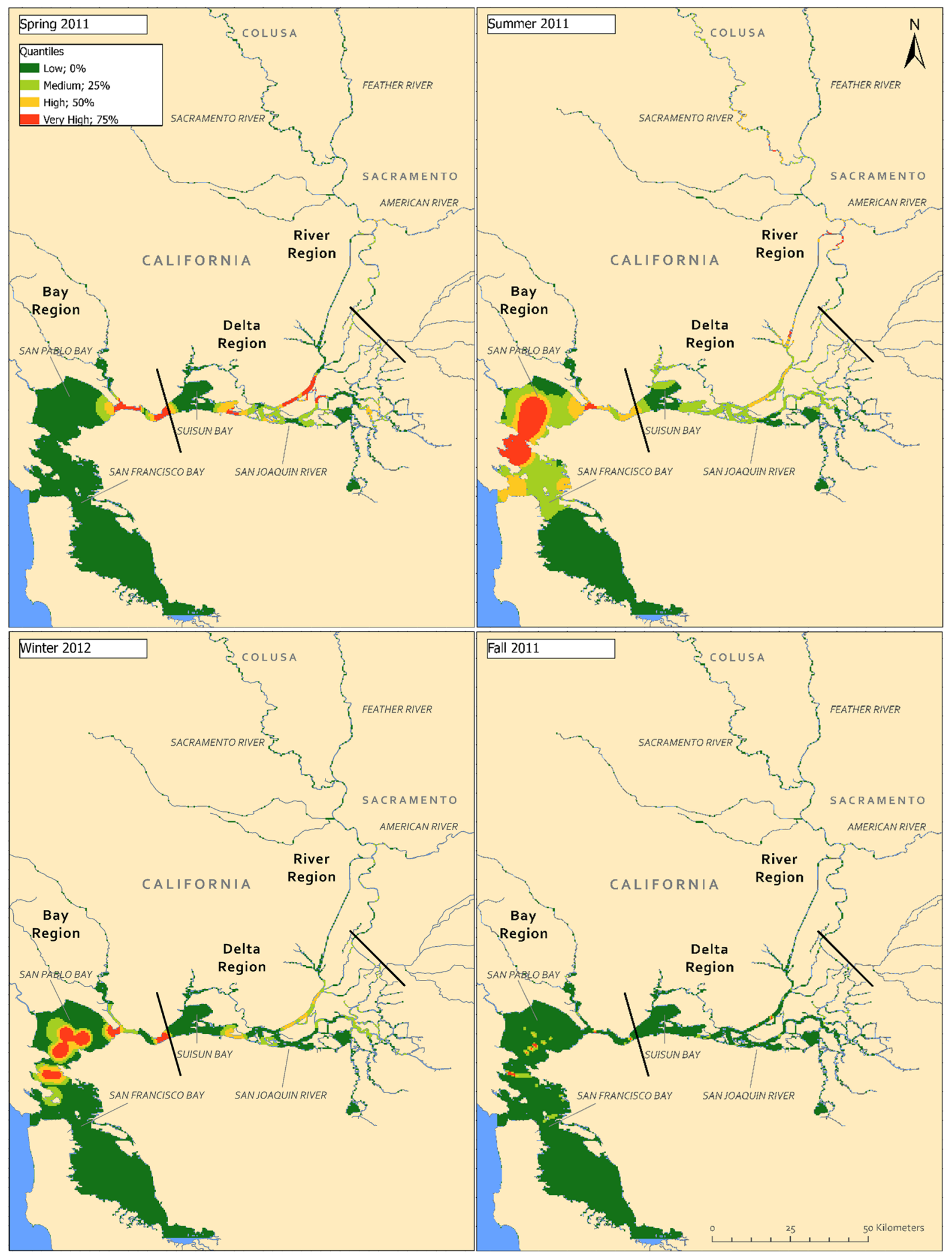


4Fig. 5 Seasonal habitat use using Kernel density interpolations of age-II and age-III sub-adult Striped Bass based upon the detections $(n=32,853)$ from spring 2011 to winter 2012 in the San Francisco Estuary Watershed

Current CDFW fishing regulations permit catching of immature females before they are able to contribute to the overall reproductive success of the population causing de facto population reduction. The impacts of catching female sub-adult Striped Bass are disproportionately high in the bay region which has a year-round commercial passenger vessel fishery and other heavily fished hotspots in the delta region. Richards and Rago (1999) provided evidence that restoration of spawning biomass led to improvements in recruitment, thus fishery management can claim some of the credit for recovery of the Atlantic Striped Bass Chesapeake Bay stock. We speculate that spawning biomass is being reduced by the removal of immature females via fishing which has contributed to the population decline observed since the 1970s, and year-round fishing in the bay region may impact the population severely.

Murphy et al. (2015) assessed fishers' support of Atlantic Striped Bass management strategies and found generally supportive or neutral views toward slot limits to increase reproductive potential and circle hooks to reduce mortality of released fish, but less supportive of reduced bag limits. Although Pacific Striped Bass is currently linked to the decline of juvenile salmonids in this highly managed and tidally influenced watershed, this species remains an economically significant and recreationally important fishery warranting additional investigation which includes stakeholders assisting with data collection and management decisions. If Striped Bass fishery management goals target maintenance of current or increase in the population, adopting strategies implemented for the Atlantic Striped Bass fishery could prove successful such as slot limits (e.g., at least 711-889 mm TL) and seasonal closures (e.g., nursery grounds and spawning areas). Conversely, if management goals target the continued reduction of the population by removal of immature females, the current size limit of $457 \mathrm{~mm}$ TL can be maintained and coupled with increased bag limits in seasonal hotspots in the bay and delta regions.

\section{Conclusion}

This study confirms that there are seasonal changes in movement and habitat use patterns in the ways in which sub-adult Striped Bass inhabit bay, delta, and riverine regions. Certain areas are high density hotspots used year-round, while others are used seasonally. Water temperature, salinity, and the combination influence habitat use with younger sub-adults seeking warm limnetic habitat, while older fish were observed in higher salinity conditions. The patterns exhibited by sub-adults in this study concurred with historic studies conducted in the $30 \mathrm{~s}$ and $60 \mathrm{~s}$. This may imply that this non-native species has somewhat adapted to the landscape-level anthropogenic impacts which have occurred since its introduction and may be more resilient than native fishes to chronic droughts and climate change impacts in the SFEW. Variation in movement patterns and habitat use indicate that sex and state of immaturity versus maturity may be as important or more so than age and length factors when understanding Striped Bass behaviors for population-level management.

Acknowledgements We greatly appreciate the experienced fishers, especially coordinator W. E. Templin, staff of the California Fish Tracking Consortium, federal and state agencies, and private consultants for providing receiver detection data. We are extremely grateful to Professor Y.G. Kim at Humboldt State for conducting the statistical analyses and Dr. E. Hines at San Francisco State for guidance on the KDE figures. We thank Drs. M.L. Johnson, S.I. Doroshov, and J.J. Isely for their contributions to earlier manuscripts. The constructive comments from two anonymous reviewers greatly strengthened the manuscript.

Author contribution Cynthia Le Doux-Bloom and A. Peter Klimley contributed to the study conception and design. Le Doux-Bloom developed and tested the tagging methods, surgically implanted the tags, assisted with GIS design, and contributed to data analyses and interpretation, writing, reviewing, and editing. Jennifer E. Hemmert downloaded and organized the detections; Rebekah S. Lane developed the GIS products and analyses and contributed to writing and reviews. Catherine A. Masatani and Grant J. Christian contributed to data analysis and assisted in writing and reviews. All authors read and approved the final manuscript.

Funding The fieldwork was supported by the California Department of Water Resources. No funding was received to assist with the preparation of this manuscript. Reference to trade names does not imply endorsement by the authors or their affiliates. The views and opinions expressed or implied in this article are those of the authors. 
Data availability Data are available upon request to corresponding author or California Fish Tracking Consortium.

Code availability Not applicable.

\section{Declarations}

Ethics approval All procedures performed were permitted by the California Department of Fish and Wildlife Scientific Collecting permit \#11017. The California Department of Water Resources did not have an IACUC (Institutional Animal Care and Use Committee) process in place at the time of the study. The collection, handling, and tagging of M. saxatilis was conducted using the best available science and veterinary practices for minimizing stress and ensuring survival with special emphasis on mitigating the effects of anesthesia and surgical implantation of acoustic tags. Surgical methods were reviewed by aquatic animal veterinary staff of the University of California, Davis, and were found to be within acceptable standards for a field based, wild-caught, acoustic telemetry fish study. This article does not contain any studies involving human participants.

Concept to participate and publication All authors participated the development of this manuscript and consented to its publication.

Competing interests The authors declare no competing interests.

Employment The authors have no relevant employment interests to disclose.

Financial interests The authors have no relevant financial interests to disclose.

Open Access This article is licensed under a Creative Commons Attribution 4.0 International License, which permits use, sharing, adaptation, distribution and reproduction in any medium or format, as long as you give appropriate credit to the original author(s) and the source, provide a link to the Creative Commons licence, and indicate if changes were made. The images or other third party material in this article are included in the article's Creative Commons licence, unless indicated otherwise in a credit line to the material. If material is not included in the article's Creative Commons licence and your intended use is not permitted by statutory regulation or exceeds the permitted use, you will need to obtain permission directly from the copyright holder. To view a copy of this licence, visit http://creativecommons.org/licenses/by/4.0/.

\section{References}

Able KW, Grothues TM (2007) Diversity estuarine movements of striped bass (Morone saxatilis): a synoptic examination of an estuarine system in southern New Jersey. Fish Bull 105:426-435

Able KW, Grothues TM, Turnure JT, Byrne DM, Clerkin P (2012) Distribution, movements, and habitat use of small striped bass (Morone saxatilis) across multiple spatial scales. Fish Bull 110:176-192

Allen T, Olds E, Southwick R, Scuderi B, Caputo L, Howlett D (2018) Sportfishing in America: an economic force for conservation. Produced for the American Sportfishing Association via Multistate Grant \#F17AP00082 awarded by the Wildlife and Sport Fish Restoration Programs of the U.S. Fish and Wildlife Service

American SportFishing Association (2021) https://asafishing. org/state-reports/economic-impacts-of-recreational-fishi ng-california. Accessed 2 May 2021

Andrews SN, Wallace B, Gautreau M, Linnansaari T, Curry RA (2018) Seasonal movements of striped bass Morone saxatilis in a large tidal and hydropower regulated river. Environ Biol Fish 101:1549-1558. https://doi.org/10. 1007/s10641-018-0799-y

Arthur JF, Botsford LW, Cannon T, Cox GC, Hansen SR (1982) The striped bass decline in the San Francisco Bay-Delta estuary. Report to the California State Water Resources Control Board, Sacramento, CA. https://swfscpublications.fisheries.noaa.gov/publications/CR/1982/ 1982Striped.pdf. Accessed 8 Sept 2020

Atlantic States Marine Fisheries Commission (2021) Atlantic striped bass. http://www.asmfc.org/species/atlantic-strip ed-bass. Accessed 2 Oct 2021

Beck MW, Heck KL, Able K (2001) The identification, conservation, and management of estuarine and marine nurseries for fish and invertebrates. Bioscience 51:633-641

Bjorgo KA, Isely JJ, Thomason CS (2000) Seasonal movement and habitat use by striped bass in the Combahee River, South Carolina. Trans Am Fish Soc 129:1281-1287

Boughton DA (2020) Striped Bass on the coast of California: a review. Calif Fish Wildl 106(3):226-257

Bridger CJ, Booth RK (2003) The effects of biotelemetry transmitter presence and attachment procedures on fish physiology and behavior. Rev Fish Sci 11:13-34

Brown JJ, Ehtisham A, Conover DO (1998) Variation in larval growth rate among striped bass stocks from different latitudes. Trans Am Fish Soc 127:598-610

Buchanan RA, Brandes PL, Skalski JR (2018) Survival of juvenile fall-run Chinook salmon through the San Joaquin River Delta, California, 2010-2015. North Am J Fish Manag 38:663-679

California Department of Fish and Game (1989) Striped bass restoration and management plan for the Sacramento-San Joaquin Estuary: phase I: Sacramento

California Department of Fish and Wildlife (2021) Inland sport fishing. https://wildlife.ca.gov/Fishing/Inland/StripedBass\#35540376-biology. Accessed 2 Oct 2021

California Fish Commission (1871) [1st Biennial] Report of the Commissioners of Fisheries of the State of California, for the years 1870 and 1871. Sacramento, CA. http:// www.californiawarden.com/Historical\%20Documents/ FishCommissionBiennialReports/BiennialReportFishAn dGameCommission1870-1871.pdf. Accessed 21 Jan 2020

California Fish Commission (1879) [5th Biennial] Report of the Commissioners of Fisheries of the State of California, 
for the years 1878 and 1879. Sacramento, CA. http:// www.californiawarden.com/Historical\%20Documents/ FishCommissionBiennialReports/BiennialReportFishAn dGameCommission1878-1879.pdf. Accessed 14 Feb 2020

Calhoun AJ (1952) Annual migrations of California striped bass. Calif Fish Game 38:391-403

Callahan J, Fisher AC, Templeton S (1989) The San Francisco Bay/Delta striped bass fishery: anatomy of a decline. UC Berkeley CUDARE Working Paper 499

Chadwick HK (1967) Recent migrations of the SacramentoSan Joaquin River striped bass population. Trans Am Fish Soc 96:327-342

Clark GH (1934) Tagging of striped bass. Calif Fish Game 20:14-19

Clark GH (1936) A second report on striped bass tagging. Calif Fish Game 22:272-283

Cloern JE, Knowles N, Brown LR, Cayan D, Dettinger MD, Morgan TL, Shoellhamer DH, Stacey MT, van der Wegen M, Wagner RW, Jassby AD (2011) Projected evolution of California's San Francisco Bay-Delta-River system in a century of climate change. PLoS ONE 6(9):e24465. https://doi.org/10.1371/journal.pone.0024465

Cohen AN, Carlton JT (1995) Nonindigenous aquatic species in a United States estuary: a case study of the biological invasions of the San Francisco Bay and Delta. SFEI Contribution No. 185. U.S. Fish and Wildlife Service, Washington DC

Conomos TJ, Smith RE, Gartner JW (1985) Environmental setting of San Francisco Bay. Hydrobiologia 129:1-12. https://doi.org/10.1007/BF00048684

Cook AM, Duston J, Bradford RG (2010) Temperature and salinity effects on survival and growth of early life stage Shubenacadie River striped bass. Trans Am Fish Soc 139:749-757

Cooper JE, Rulifson RA, Isely JJ, Winslow SE (1998) Food habits and growth of juvenile striped bass, Morone saxatilis, in Albemarle Sound, North Carolina. Estuaries 21:307-317

Coutant CC (1985) Striped bass, temperature, and dissolved oxygen: a speculative hypothesis for environmental risk. Trans Am Fish Soc 114:31-61

Coutant CC (1986) Thermal niches of striped bass. Sci Am 255:98-105

Cox DK, Coutant CC (1981) Growth dynamics of juvenile striped bass as functions of temperature and ration. Trans Am Fish Soc 110:226-238

Dudley RG, Mullis AW, Terrell JW (1977) Movements of adult striped bass (Morone saxatilis) in the Savannah River, Georgia. Trans Am Fish Soc 106:314-322

Edwards GB (1969) Literature review of the striped bass Roccus saxatilis (Walbaum). http://www.nativefishlab.net/ library/textpdf/15768.pdf. Accessed 26 June 2020

Federal Geographic Data Committee (2012) Coastal and marine ecological classification standard, FGDCSTD-018-2012. Federal Geographic Data Committee, Reston. https://www.fgdc.gov/standards/projects/cmecsfolder/CMECS_Version_06-2012_FINAL.pdf. Accessed 6 Aug 2020

Forrester CR, Peden AE, Wilson RM (1972) First records of the striped bass, Morone saxatilis in British Columbia waters. J Fish Res Board Can 29:337-339
Haeseker SL, Carmichael JT, Hightower JE (1996) Summer distribution and condition of striped bass within Albemarle Sound, North Carolina. Trans Am Fish Soc 125:690-704

Hollema HM, Kneebone J, McCormick SD, Skomal GB, Danylchuk AJ (2017) Movement patterns of striped bass (Morone saxatilis) on a tidal coastal embayment in New England. Fish 187:168-177

Kneebone J, Hoffman WS, Dean MJ, Armstrong MP (2014) Movements of striped bass between the exclusive economic zone and Massachusetts state waters. N Am J Fish Manag 4:524-534

Kohlenstein LC (1981) On the proportion of the Chesapeake stock of striped bass that migrates into the coastal fishery. Trans Am Fish Soc 110:168-179

Lackey RT (2009) Salmon decline in Western North America: historical context. In: Encyclopedia of earth. Eds. Cutler J. Cleveland (Washington, DC, Environmental Information Coalition, National Council for Science and the Environment). http://www.eoearth.org/article/Salmon_in_weste rn_North_America:_assessing_the_future

Lal K, Lasker R, Kuljis A (1977) Acclimation and rearing of striped bass larvae in seawater. Calif Fish Game 63:210-218

Le Doux-Bloom CM (2012) Distribution, habitat use, and movement patterns of sub-adult striped bass (Morone saxatilis) in the San Francisco Estuary Watershed, California. Dissertation, University of California, Davis

Lemm CA (1993) Evaluation of five anesthetics on striped bass. National Fisheries Research Centre Technical Report 196, National Fisheries Research Center B, Leetown, Kearneysville

Lindley ST, Mohr MS (2002) Modeling the effect of striped bass (Morone saxatilis) on the population viability of Sacramento River winter-run Chinook salmon (Oncorhynchus tshawytscha). Fish Bull 101:321-331

Mansueti RJ (1961) Age, growth and movements of the striped bass, Roccus saxatilis, taken in size selective fishing gear in Maryland. Chesap Sci 2:9-36

Mather ME, Finn JT, Pautzke SM, Fox D, Savoy T, Brundange HM, Deegan LA, Muth RM (2010) Diversity in destinations, routes, and timing of small adult and sub-adult striped bass Morone saxatilis on their southward autumn migration. J Fish Biol 77:2326-2337

Merriman D (1941) Studies on the striped bass (Roccus saxatilis) of the Atlantic coast. United States Fish and Wildlife Fishery Bulletin 50:1-77

Morgan AR, Gerlach AR (1950) Striped bass studies on Coos Bay Oregon in 1949 and 1950. Oregon Fish Commission Contribution 14

Murphy RD, Scyphers SB, Grabowski JH (2015) Assessing fishers' support of striped bass management strategies. PLoS ONE 10(8):e0136412

Nemerson DM, Able KW (2003) Spatial and temporal patterns in the distribution and feeding habits of Morone saxatilis in marsh creeks of Delaware Bay, USA. Fish Manag Ecol 10:337-348. https://doi.org/10.1046/j.1365-2400.2003. 00371

Ng CL, Able KW, Grothues TM (2007) Habitat use, site fidelity, and movement of adult striped bass in a southern New 
Jersey estuary based on mobile acoustic telemetry. Trans Am Fish Soc 136:1344-1355

Patrick WS, Rulifson RA, Stellwag EJ (2006) An investigation of Roanoke River striped bass migratory behavior using genetic and PIXE analysis. Final Report to NC Sea Grant, FRG 04-EP-08

Pautzke SM, Mather ME, Finn JT, Deegan LA, Muth RM (2010) Seasonal use of a New England estuary by foraging contingents of migratory striped bass. Trans Am Fish Soc 139:257-269

Pincock DG (2012) False detections: what are they and how to remove them from detection data. Amirix Document DOC-004691 Version 03. http://vemco.com/wp-content/ uploads/2012/11/false_detections.pdf. Accessed 26 June 2019

Pope AC, Perry RW, Harvey BN, Hance DJ, Hansel HC (2021) Juvenile Chinook salmon survival, travel time, and floodplain use relative to riverine channels in the SacramentoSan Joaquin River Delta. Trans Am Fish Soc 150:38-55

R Core Team (2020) R: a language and environment for statistical computing. R Foundation for Statistical Computing, Vienna. https://www.R-project.org/. Accessed 12 Aug 2021

Raney EC (1952) The life history of the striped bass, Roccus saxatilis (Walbaum). Bull of Bingham Oceanography Collection 14:5-97

Richards RA, Rago PJ (1999) A case history of effective fishery management: Chesapeake Bay striped bass. N Am J Fish Manage 19:356-375

Robinson JB (1960) The age and growth of striped bass (Roccus saxatilis) in California. Calif Fish Game 46:279-290

Rulifson RA, Dadswell MJ (1995) Life history and population characteristics of striped bass in Atlantic Canada. Trans Am Fish Soc 124:477-507

Sabal MC, Michel CJ, Smith JM, Hampton A, Hayes SA (2019) Seasonal movement patterns of striped bass (Morone saxatilis) in their nonnative range. Estuar Coast 42:567-579. https://doi.org/10.1007/s1237-018-0467-7

Scofield NB, Bryant HC (1926) The striped bass in California. Calif Fish Game 12:55-74

Secor DH, Piccoli PM (1996) Age- and sex-dependent migrations of the Hudson River striped bass population determined from otolith microanalysis. Estuaries 19:778-793

Silverman BW (1986) Density estimation for statistics and data analysis. Chapman and Hall, New York

Skinner JE (1962) An historical review of the fish and wildlife resources of the San Francisco Bay area. Calif Fish Game Water Projects Branch Rep 1:1-225

Smith HM (1895) A review of the results of attempts to acclimatize fish and other water animals in the Pacific States. Bulletin of the U.S. Fish Commission pp 379-469
Smith SE, Kato S (1979) The fisheries of San Francisco Bay: past, present, and future. In Conomos TJ (ed) San Francisco Bay: the urbanized estuary. Pacific Division, Am Assoc Adv Sci San Francisco, CA pp 445-468

Smultea M, Jefferson TJ, Lane R (2021) Marine mammal seasonal occurrence, distribution, behavior, and abundance in Puget Sound, Washington during aerial surveys from 2013-2016. Northwestern Naturalist

Sommer T (2020). How to respond? An introduction to current bay-delta natural resources management options. San Franc Estuary and Watershed Sci 18(3) https://doi.org/10. 15447//SFEWWs.2020v18iss3art1

Stevens RE (1957) The striped bass of the Santee-Cooper Reservoir. Proc. Ann Conf South-Eastern Assoc Game and Fish Commissioners 11:253-265

Stevens DE, Kohlhorst DW, Miller LW, Kelley DW (1985) The decline of striped bass in the Sacramento-San Joaquin Estuary, California. Trans Am Fish Soc 114:12-30

Tipsmark CK, Madsen SS, Borski RJ (2004) Effect of salinity on expression of branchial ion transporters in striped bass (Morone saxatilis). J Exp Zool A Comp Exp Biol 12:979-991

Towle JC (2000) Authored ecosystems: Livingston Stone and the transformation of California fisheries. Environ Hist 5(1):54-74. https://doi.org/10.2307/3985535

Turner JL, Kelley DW (1966) Fish Bulletin 136. Ecological studies of the Sacramento-San Joaquin Delta. Part II: fishes of the delta. UC San Diego: Library-Scripps Digital Collection. https://escholarship.org/uc/item/4z31776k. Accessed 26 Feb 2021

Waldman JR, Dunning DJ, Ross QE, Mattson MT (1990) Range dynamics of Hudson River striped bass along the Atlantic Coast. Trans Am Fish Soc 119:910-919

Wingate RL, Secor DH (2007) Intercept telemetry of the Hudson River striped bass resident contingent: migration and homing patterns. Trans Am Fish Soc 136:95-104

Wingate RL, Secor DH, Kraus RT (2011) Seasonal patterns of movement and residency by striped bass within a sub-estuary of the Chesapeake Bay. Trans Am Fish Soc 140:1441-1450

Publisher's note Springer Nature remains neutral with regard to jurisdictional claims in published maps and institutional affiliations. 